\title{
Review
}

\section{Valorisation of Starch Wastewater by Anaerobic Fermentation}

\author{
Bernhard Drosg ${ }^{1,2, *}$, Matthias Neubauer ${ }^{1}$, Marceli Marzynski ${ }^{1}$ and Katharina Meixner ${ }^{1,2} \mathbb{0}$ \\ 1 BEST—Bioenergy and Sustainable Technologies, Research Site Tulln, Konrad-Lorenz Str. 20, \\ 3430 Tulln, Austria; matthias.neubauer@best-research.eu (M.N.); marceli.marzynski@best-research.eu (M.M.); \\ katharina.meixner@best-research.eu (K.M.) \\ 2 Department of Agrobiotechnology, Institute of Environmental Biotechnology, IFA-Tulln, \\ University of Natural Resources and Life Sciences, Vienna, Konrad-Lorenz Str. 20, 3430 Tulln, Austria \\ * Correspondence: bernhard.drosg@best-research.eu; Tel.: +43-5-02378-9428
}

Citation: Drosg, B.; Neubauer, M.;

Marzynski, M.; Meixner, K.

Valorisation of Starch Wastewater by Anaerobic Fermentation. Appl. Sci. 2021, 11, 10482. https://doi.org/ 10.3390/app112110482

Academic Editor: Günther Bochmann

Received: 20 September 2021

Accepted: 25 October 2021

Published: 8 November 2021

Publisher's Note: MDPI stays neutral with regard to jurisdictional claims in published maps and institutional affiliations.

Copyright: (c) 2021 by the authors. Licensee MDPI, Basel, Switzerland. This article is an open access article distributed under the terms and conditions of the Creative Commons Attribution (CC BY) license (https:/ / creativecommons.org/licenses/by/ $4.0 /)$.
Abstract: Starch production is mainly focused on feedstocks such as corn, wheat and potato in the EU, whereas cassava, rice, and other feedstocks are utilised worldwide. In starch production, a high amount of wastewater is generated, which accumulates from different process steps such as washing, steeping, starch refining, saccharification and derivatisation. Valorisation of these wastewaters can help to improve the environmental impact as well as the economics of starch production. Anaerobic fermentation is a promising approach, and this review gives an overview of the different utilisation concepts outlined in the literature and the state of the technology. Among bioenergy recovery processes, biogas technology is widely applied at the industrial scale, whereas biohydrogen production is used at the research stage. Starch wastewater can also be used for the production of bulk chemicals such as acetone, ethanol, butanol or lactic acids by anaerobic microbes.

Keywords: starch wastewater; anaerobic digestion; biogas; biohydrogen; ABE fermentation; lactic acid

\section{Introduction}

Starch is an industrial commodity produced for the food, packaging and pharmaceutical markets with a growing production volume of 150 million tonnes in 2020 and set to surpass 165 million tonnes in 2026 [1]. In the EU the annual production volume stands at 11 million tonnes of starch and starch derivatives (which is an increase of approximately 3 million tonnes from 2004), extracted from around 25 million tonnes of raw materials. Of this annual output, 9 million tonnes are utilised domestically, the majority of it being starch sweeteners [2].

The main feedstocks in the EU production market are corn, wheat and potatoes; however, a wide range of feedstocks is applied worldwide: cassava, rice, rye, barley, oat, milo, sweet potatoes and sago palms [3]. One of the challenges in industrial starch production is the accumulation of large amounts of high strength wastewaters. Depending on feedstocks and technologies, different kinds of wastewater can occur at different steps of the process: (1) washing of the feedstocks (e.g., potatoes), (2) steeping of the feedstocks (corn), (3) starch refinement (e.g., corn gluten water), (4) starch saccharification (e.g., glucose wastewater); (5) modification of the starch [3-5]. Some of these processes are thermal (evaporation, drying), where condensates accumulate. In general, starch production processes have been optimised throughout the decades so that wastewaters are often re-used internally to reduce their amounts. Anaerobic fermentation, especially of the wastewaters containing higher COD concentrations, is of interest.

Anaerobic biotechnological processes such as biogas, biohydrogen, lactic acid and acetone-butanol-ethanol (ABE) fermentations can be interesting approaches to utilise starch wastewaters. It is often not necessary to provide sterile conditions, which reduces costs and efforts decisively. The variety of the product range is attractive and can range from energy carriers to bulk chemicals. 
In the scientific literature, an overview of the different anaerobic valorisation possibilities of starch wastewater is lacking. Recent works mainly focus on only biohydrogen production from starch wastewater [4]; others on only biogas production $[3,6]$. There are also some papers on a combined production in a two-step process [7]. Other authors give an overview of biohydrogen production from different wastewaters [8] but do not focus on starch wastewaters. The wastewater treatment perspective is intrinsic in other publications [5,9] and not the product range. However, from an industrial perspective, it is of interest to give a comprehensive comparison of the existing different anaerobic valorisation options for the different types of starch wastewater. This review aims at filling this gap.

\section{Biogas Production}

The anaerobic digestion process for the treatment of starch wastewater is commonly applied at an industrial scale. The main idea is to convert most of the carbon sources present in the wastewater into biogas which can be used to replace fossil resources (e.g., natural gas) in the starch production facility. The effluent of the anaerobic reactor is then treated in an activated sludge process [9]. In the scientific literature, detailed aspects of the anaerobic digestion of starch wastewater are discussed, which are described in the following.

\subsection{Reactor Types}

Examples of industrial-scale applications for the anaerobic digestion of starch wastewater are described by Bischofsberger et al. [3]. Common approaches are UASB (upflow anaerobic sludge blanket) as well as for increased $\mathrm{kg} \mathrm{COD} \mathrm{m}^{-3} \mathrm{~d}^{-1}$ rates, EGSB (expanded granular sludge bed) reactors. The two systems differ in reactor design and influx rate. Whereas UASB reactors are commonly built to be wider in diameter and rather shorter in height, EGSB reactors are known for the opposite. As described in Speece [10], the increased influx rate as well as the smaller diameter expand the granular sludge bed and perform an increased fluidisation. Therefore, a higher contact rate between sludge and wastewater is achieved compared to UASB reactors. Bischofsberger et al. [3] also describe modified anaerobic filters which are applied in the starch industry. In these reactors, the biomass is attached to a fixed/packed bed in the reactor. In the literature, other interesting reactor types are described for starch wastewater treatment: anaerobic baffled reactor [11], up-flow multistage anaerobic reactor [12] and anaerobic tapered fluidised bed reactor [13]. For small-scale starch production in Colombia, the flow filter with bamboo as a support is described [14]. Finally, the anaerobic pond treatment of starch wastewater should also be mentioned. Rajbhandari and Annachhatre describe such a case study in Thailand [15]. However, these ponds often operated uncovered, with the main focus on the treatment of the wastewater. Consequently, biogas is directly released to the atmosphere and not recovered for the process. Fortunately, there are approaches to cover such lagoons and recover the methane produced [6].

\subsection{Degradation Performance}

Industrial-scale applications showed organic loading rates (OLR) of $15-20 \mathrm{~kg} \mathrm{COD} \mathrm{m}^{-3} \mathrm{~d}^{-1}$ in UASB reactors for potato starch wastewater. For corn starch wastewater, $25-30 \mathrm{~kg}$ COD m${ }^{-3} \mathrm{~d}^{-1}$ was achieved in ANAFLUX fluidised bed reactors, when referring to the active volume of the reactor, and $15 \mathrm{kgCOD} \mathrm{m}^{-3} \mathrm{~d}^{-1}$, when referring to the overall volume of the reactor (including the settling zone). In anaerobic filter treatment of wheat starch wastewater, an OLR of 7-10 $\mathrm{kg}$ COD m$^{-3} \mathrm{~d}^{-1}$ could be achieved [3].

Table 1 shows the results from lab trials. OLR of 3-8 $\mathrm{kg} \mathrm{COD} \mathrm{m}^{-3} \mathrm{~d}^{-1}$ could be applied in UASB/EGSB reactors without recirculation, and $25 \mathrm{~kg} \mathrm{COD} \mathrm{m}^{-3} \mathrm{~d}^{-1}$ in an UASB reactor with recirculation [16-18]. Methane yields varied between 160 and $332 \mathrm{~L}$ $\mathrm{CH}_{4} \mathrm{~kg} \mathrm{COD}^{-1}$. 
Table 1. Methane yields and organic loading rates from different starch wastewaters in UASB/EGSB lab-scale reactors.

\begin{tabular}{|c|c|c|c|c|}
\hline Feedstock & Reactor & $\begin{array}{c}\text { OLR } \\
\left(\mathrm{kg} \mathrm{COD} \mathrm{m}^{-3} \mathrm{~d}^{-1}\right)\end{array}$ & $\begin{array}{c}\text { Methane Yield } \\
\left(\mathrm{L} \mathrm{CH}_{4} \mathrm{~kg} \mathrm{COD}^{-1}\right)\end{array}$ & Literature \\
\hline Potato juice & UASB & 5.1 & 210 & [16] \\
\hline Potato juice & EGSB & 3.2 & 332 & [16] \\
\hline Synthetic starch wastewater & UASB & 4 & 325 & [17] \\
\hline $\begin{array}{l}\text { Modified tapioca starch } \\
\text { wastewater }\end{array}$ & UASB & 7.5 & 160 & [18] \\
\hline $\begin{array}{l}\text { Modified tapioca starch } \\
\text { wastewater }\end{array}$ & $\begin{array}{l}\text { UASB (with } \\
\text { recirculation flow) }\end{array}$ & 25 & 240 & [18] \\
\hline
\end{tabular}

\subsection{Pre-Acidification Step}

At industrial scale, a pre-acidification step prior to UASB reactors is frequently applied. However, in the literature, detailed evaluations of this step, which would improve the process, are often not provided. With regard to starch wastewater, Wu et al. (2020) demonstrated that a two-step UASB process showed a higher degradation performance, as well as an improved process stability [19]. The latter was especially due to increased granule quality: strength, settling capability, morphological features and quality of the extracellular polymeric substances (EPS). Wu et al. (2021) described that the UASB granules with a pre-acidification step are more robust with regard to changing substrate quality and show superior stability in the microbial community structure [19]. All in all, the scientific literature proposes the pre-acidification step as beneficial when treating starch wastewaters.

\subsection{Granule Stability and Microbial Composition (UASB Reactor)}

$\mathrm{Lu}$ et al. (2018) found that the relation of $\mathrm{COD} / \mathrm{SO}_{4}{ }^{2-}$ had an effect on the granule composition [17]. Suitable sulphate addition $\left(\mathrm{COD} / \mathrm{SO}_{4}{ }^{2-} \geq 2\right)$ enriched granular microecosystems and stimulated the secretion of extracellular substances. This had the positive effect of cell cohesion and sludge aggregation. The results also show that when decreasing from high sulphate concentrations to moderate sulphate concentrations, the granule size increased drastically. Generally, starch-fed granules tended to form flagella-like filaments on the surface. The filaments were overwhelmed by hydrophilic biopolymers and showed an affinity for biogas bubbles and water molecules. For this reason, granule flotation and washout were increased.

Other researchers carried out qualitative and quantitative analysis of the bacterial and archaeal population in the sludge [20]. They found out that Firmicutes and Chloroflexi bacterial groups dominated the bottom and top section of their UASB, respectively, whereas the middle section was dominated by Euryarchaeota (Methanosaeta). These findings provide guidance for optimising UASB performance [21].

\subsection{Modelling of the Degradation Process (UASB Reactor)}

As anaerobic digestion is a complex process, increasing work is being carried out to model the degradation of starch wastewater. This can help to predict the process development and increase the stability. A neural network model was used to evaluate the COD removal with $\mathrm{pH}, \mathrm{COD}, \mathrm{NH}_{4}{ }^{+}, \mathrm{VFA}, \mathrm{OLR}$ and biogas yield as input variables [22]. Results from the modelling show high forecast accuracy; only 13\% of the variation in the COD removal could not be explained. For the simulation of starch wastewater degradation, the Anaerobic digestion model No. 1 (ADM1) was also used [23]. The model was adapted for lactate formation and degradation and could then be successfully applied.

\section{Biohydrogen Production}

Hydrogen is currently hyped as a future renewable energy carrier. Current hydrogen on the market is mainly produced from fossil resources. However, it is possible to 
produce hydrogen from organic feedstocks by fermentation. In the case that biohydrogen is produced from wastewater, anaerobic dark fermentation is typically applied. This fermentation is part of the anaerobic digestion process, where methanogenesis is suppressed. Biohydrogen production is still in its infancy and is not applied at the industrial scale. The results of biohydrogen lab-scale experiments are shown in Table 2. Wang et al. worked with two isolated strains and achieved $186.3 \mathrm{~L} \mathrm{H}_{2} \mathrm{~kg} \mathrm{COD}^{-1}$ with a mixture of corn gluten water and corn steep liquor [4]. They demonstrated that these starch wastewaters were excellent feedstocks for biohydrogen production. The hydrogen production rate of $165.89 \mathrm{~mL} \mathrm{~L}^{-1} \mathrm{~h}^{-1}$ was about 21 times higher than the reference using starch as a carbon source and peptone as a nitrogen source. Khongkliang et al. achieved even higher yields of $260 \mathrm{~L} \mathrm{H}_{2} \mathrm{~kg} \mathrm{COD}^{-1}$ when using wastewater from cassava processing in thermophilic fermentation [7].

Table 2. Biohydrogen yields and productivity from different starch wastewaters and under varying experimental conditions.

\begin{tabular}{|c|c|c|c|c|}
\hline Feedstock & Details on Experiments & $\begin{array}{c}\text { Biohydrogen Yield } \\
\left(\mathrm{L} \mathrm{H}_{2} \mathrm{~kg} \mathrm{COD}^{-1}\right)\end{array}$ & $\begin{array}{l}\text { Biohydrogen Productivity } \\
\qquad\left(\mathrm{mL} \mathrm{H} \mathrm{H}_{2} \mathrm{~L}^{-1} \mathrm{~d}^{-1}\right)\end{array}$ & Literature \\
\hline $\begin{array}{l}\text { Corn gluten water, corn } \\
\text { steep liquor }\end{array}$ & Two isolated strains & 186.3 & 3981 & [4] \\
\hline $\begin{array}{l}\text { Cassava starch } \\
\text { processing wastewater }\end{array}$ & Thermophilic fermentation & 260 & 2163 & [7] \\
\hline $\begin{array}{l}\text { Cassava starch } \\
\text { wastewater }\end{array}$ & With base-treated bacteria & 37.4 & 3348 & [24] \\
\hline $\begin{array}{l}\text { Cassava starch } \\
\text { wastewater }\end{array}$ & With acid-treated bacteria & 22.6 & 914.4 & [24] \\
\hline $\begin{array}{l}\text { Cassava starch } \\
\text { wastewater }\end{array}$ & Co-digestion with buffalo dung & 16.9 & 839 & [25] \\
\hline $\begin{array}{l}\text { Synthetic cassava } \\
\text { starch wastewater }\end{array}$ & $\begin{array}{l}\text { Two-stage process with additional } \\
\text { methane production }\end{array}$ & 81.5 & - & [26] \\
\hline Corn starch wastewater & $\begin{array}{l}\text { Thermophilic hydrogen } \\
\text { fermentation (mixed culture) and } \\
\text { subsequent methanogenic step }\end{array}$ & 141.9 & 3450 & [27] \\
\hline
\end{tabular}

Comparably low hydrogen yields were obtained by Sinbuathong et al. [24]. They worked with mixed-cultures and achieved hydrogen yields of $37.4 \mathrm{~L} \mathrm{H}_{2} \mathrm{~kg} \mathrm{COD}^{-1}$ with base-treated bacteria and $22.6 \mathrm{~L} \mathrm{H}_{2} \mathrm{~kg} \mathrm{COD}^{-1}$ with acid-treated bacteria. Wadjeam et al. achieved $16.9 \mathrm{~L} \mathrm{H}_{2} \mathrm{~kg} \mathrm{COD}^{-1}$ in starch wastewater co-digestion with buffalo dung [25].

In the literature, combined hydrogen and methane production is also described, where yields of $81.5 \mathrm{~L} \mathrm{H}_{2} \mathrm{~kg} \mathrm{COD}^{-1}$ and $310.5 \mathrm{~L} \mathrm{CH}_{4} \mathrm{~kg} \mathrm{COD}^{-1}$ [26] as well as $141.9 \mathrm{~L} \mathrm{H}_{2} \mathrm{~kg} \mathrm{COD}^{-1}$ and $230 \mathrm{~L} \mathrm{CH}_{4} \mathrm{~kg} \mathrm{COD}^{-1}$ (removed) [27] were determined.

\section{Other Anaerobic Fermentations}

\subsection{Acetone-Butanol-Ethanol (ABE) Fermentation}

The fermentation products acetone, butanol and ethanol can be used as bulk chemicals in industry. In addition, ethanol and butanol can be applied as biofuels. Luo et al. investigated wheat starch wastewater for ABE fermentation [28]. They utilised a wastewater termed "suspensions after hydrocyclone centrifugation" as a main carbon source, which contained $68.6 \mathrm{~g} \mathrm{~L}^{-1}$ of starch and $48.1 \mathrm{~g} \mathrm{~L}^{-1}$ crude fibre. Corn steep liquor was used as nitrogen source. In the fermentation, they obtained $11.6 \mathrm{~g} \mathrm{~L}^{-1}$ of butanol and total solvent of $18.3 \mathrm{~g} \mathrm{~L}^{-1}$. In the literature, $\mathrm{ABE}$ fermentation trials on tapioca starch wash wastewater can also be found, where the highest butanol concentrations were achieved of $1.8 \mathrm{~g} \mathrm{~L}^{-1}$ at pH 5.5 with C. butyricum [29]. 


\subsection{Lactic Acid Fermentation}

Lactic acid can be used as a chemical in the food and feed industry; in addition, it is the precursor of the biopolymer poly-lactic acid (PLA). The traditional method of biological production of lactic acid from wastewater involves a two-step process where the substrate requires energy-intensive pre-treatment. Tosungnoen et al. showed that Lactobacillus plantarum was capable of utilising synthetic cassava starch wastewater for the production of lactic acid in a process known as simultaneous saccharification and fermentation (SSF), which is a more efficient method, compared to the traditional two-step process. Lactic acid concentrations of $28.71 \mathrm{~g} \mathrm{~L}^{-1}$ could be achieved under non-sterile conditions. At the same time, high purification rates could be achieved: COD removal of $98 \%$ and nitrogen (TKN) removal of $85 \%$ [30].

Similar results could be achieved with potato starch wastewater and the use of fungi such as Rhizopus oryzae, as demonstrated by Huang et al. with concentrations of lactic acid above $10 \mathrm{~g} \mathrm{~L}^{-1}$ at various $\mathrm{pH}$ levels, as well as an increase in fungal biomass [31]. The use of fungi brings some advantages with regard to use in an industrial environment due to their robustness and high tolerances. To combat the inhibition effect that high concentrations of lactic acid can have on microbial activity, supplementing the media with $\mathrm{CaCO}_{3}$ is possible [32]. Besides the examples presented, there are many bacterial species that have been proven to show the ability to produce lactic acid, including Carnobacterium, Leuconostoc, Streptococcus and Oenococcus [33].

\section{Conclusions}

Starch production results in increasing amounts of wastewater worldwide. In the context of a circular economy, it makes sense to valorise starch wastewaters to products which can be provided to society. Anaerobic fermentation processes are suitable approaches to provide energy carriers and bulk chemicals from starch wastewaters. Biogas production is widely applied at the industrial scale, whereas biohydrogen, ABE fermentation and lactic acid are still at the research stage. With regard to biogas research and process optimisation, current work is focussing on: further development of reactor types; improving process performance and stability; increasing the efficiency of a pre-acidification step; and process modelling. In addition, microbial consortia composition and granule stability are of high interest. With regard to biohydrogen, the research activities are more basic: determining biohydrogen yields with regard to different strains and wastewaters; evaluation of optimal fermentation parameters; strain isolation and comparison; and mixed-culture fermentations.

Author Contributions: Conceptualisation, B.D. and K.M.; writing-original draft preparation, B.D., K.M., M.N. and M.M.; writing-review and editing, B.D. and K.M.; supervision, B.D. All authors have read and agreed to the published version of the manuscript.

Funding: The research leading to these results has received funding from the COMET program managed by the Austrian Research Promotion Agency under grant number 869341. The program is co-financed by the Republic of Austria and the Federal Provinces of Lower Austria, Styria and Vienna.

Conflicts of Interest: The authors declare no conflict of interest.

\section{References}

1. Global Starch Industry, ReportLinker. Available online: https://www.reportlinker.com/p05485911/Global-Starch-Industry.html? utm_source=GNW (accessed on 11 October 2021).

2. Starch Europe. Available online: https://starch.eu/ (accessed on 11 October 2021).

3. Bischofsberger, W.; Dichtl, N.; Rosenwinkel, K.H.; Seyfried, C.F.; Böhnke, B. Anaerobtechnik, 2nd ed.; Springer: Berlin/Heidelberg, Germany, 2005; pp. 396-417.

4. Wang, S.; Zhang, T.; Su, H. Enhanced hydrogen production from corn starch wastewater as nitrogen source by mixed cultures. Renew. Energy 2016, 96, 1135-1141. [CrossRef]

5. Shubhaneel, N.; Apurba, D.; Kumar, C.P. Corn starch industry wastewater pollution and treatment-A review. J. Biodivers. Environ. Sci. 2018, 12, 283-293. 
6. Santos Sánchez, A.; Lopes Silva, Y.; Araújo Kalid, R.; Cohim, E.; Andrade Torres, E. Waste bio-refineries for the cassava starch industry: New trends and review of alternatives. Renew. Sustain. Energy Rev. 2017, 73, 1265-1275. [CrossRef]

7. Khongkliang, P.; Kongjan, P.; Utarapichat, B.; Reungsang, A.; O-Thong, S. Continuous hydrogen production from cassava starch processing wastewater by two-stage thermophilic dark fermentation and microbial electrolysis. Int. J. Hydrogen Energy 2017, 42 , 27584-27592. [CrossRef]

8. Sivagurunathan, P.; Kumar, G.; Kim, S.H.; Kobayashi, T.; Xu, K.Q.; Guo, W.; Hao Ngo, H. Enhancement Strategies for Hydrogen Production from Wastewater: A Review. Curr. Org. Chem. 2016, 20, 2744-2752. [CrossRef]

9. Sklyar, V.; Epov, A.; Gladchenko, M.; Danilovich, D.; Kalyuzhnyi, S. Combined biologic (anaerobic-aerobic) and chemical treatment of starch industry wastewater. Appl. Biochem. Biotechnol. 2003, 109, 253-262. [CrossRef]

10. Speece, R.E. Anaerobic Biotechnology for Industrial Wastewaters, 1st ed.; Archae Press: Nashville, TN, USA, 1996 ; pp. 130-154.

11. Movahedyan, H.; Assadi, A.; Parvaresh, A. Performance evaluation of an anaerobic baffled reactor treating wheat flour starch industry wastewater. Iran. J. Environ. Health Sci. Eng. 2007, 4, 77-84.

12. Sun, L.; Wan, S.; Yu, Z.; Wang, Y.; Wang, S. Anaerobic biological treatment of high strength cassava starch wastewater in a new type up-flow multistage anaerobic reactor. Bioresour. Technol. 2021, 104, 280-288. [CrossRef]

13. Parthiban, R.; Iyer, P.; Sekaran, G. Anaerobic tapered fluidized bed reactor for starch wastewater treatment and modelling using multilayer perceptron neural network. J. Environ. Sci. 2007, 19, 1416-1423.

14. Colin, X.; Farinet, J.L.; Rojas, O.; Alazard, D. Anaerobic treatment of cassava starch extraction wastewater using a horizontal flow filter with bamboo as support. Bioresour. Technol. 2007, 98, 1602-1607. [CrossRef]

15. Rajbhandari, B.K.; Annachhatre, A.P. Anaerobic ponds treatment of starch wastewater: Case study in Thailand. Bioresour. Technol. 2004, 95, 135-143. [CrossRef]

16. Fang, C.; Boe, K.; Angelidaki, I. Biogas production from potato-juice, a by-product from potato-starch processing, in upflow anaerobic sludge blanket (UASB) and expanded granular sludge bed (EGSB) reactors. Bioresour. Technol. 2011, 102, 5734-5741. [CrossRef]

17. Lu, X.; Ni, J.; Zhen, G.; Kubota, K.; Li, Y.Y. Response of morphology and microbial community structure of granules to influent COD/SO42- ratios in an upflow anerobic sludge blanket (UASB) reactor treating starch wastewater. Bioresour. Technol. 2018, 256, 456-465. [CrossRef]

18. Racho, P.; Pongampornnara, A. Enhanced biogas production from modified tapioca starch wastewater. Energy Rep. 2020, 6, 744-750. [CrossRef]

19. Wu, J.; Jiang, B.; Feng, B.; Li, L.; Moideen, S.N.; Chen, H.; Mribet, C.; Li, Y.Y. Pre-acidification greatly improves granules physicochemical properties and operational stability of Upflow anaerobic sludge Blanket (UASB) reactor treating low-strength starch wastewater. Bioresour. Technol. 2020, 302, 122810. [CrossRef] [PubMed]

20. Antwi, P.; Li, J.; Boadi, P.O.; Meng, J.; Quashie, F.K.; Wang, X.; Ren, N.; Buelna, G. Efficiency of an upflow anerobic sludge blanket reactor treating potato starch processing wastewater and related process kinetics, functional microbial community and sludge morphology. Bioresour. Technol. 2017, 239, 105-116. [CrossRef]

21. Antwi, P.; Li, J.; Boadi, P.O.; Meng, J.; Shi, E.; Xue, C.; Zhang, Y.; Ayivi, F. Functional bacterial and archaeal diversity revealed by 16S rRNA gene pyrosequencing during potato starch processing wastewater treatment in an UASB. Bioresour. Technol. 2017, 235, 348-357. [CrossRef] [PubMed]

22. Antwi, P.; Li, J.; Meng, J.; Deng, K.; Quashie, F.K.; Li, J.; Boadi, P.O. Feedforward neural network model estimating pollutant removal process within mesophilic upflow anaerobic sludge blanket bioreactor treating industrial starch processing wastewater. Bioresour. Technol. 2018, 257, 102-112. [CrossRef] [PubMed]

23. Hinken, L.; Huber, M.; Weichgrebe, D.; Rosenwinkel, K.H. Modified ADM1 for modelling an UASB reactor laboratory plant treating starch wastewater and synthetic substrate load tests. Water Res. 2014, 64, 82-93. [CrossRef]

24. Sinbuathong, N.; Sillapacharoenkul, B. Dark fermentation of starch factory wastewater with acid- and base-treated mixed microorganisms for biohydrogen production. Int. J. Hydrogen Energy 2021, 46, 16622-16630. [CrossRef]

25. Wadjeam, P.; Reungsang, A.; Imai, T.; Plangklang, P. Co-digestion of cassava starch wastewater with buffalo dung for bio-hydrogen production. Int. J. Hydrogen Energy 2019, 44, 14694-14706. [CrossRef]

26. Khongkliang, P.; Kongjan, P.; O-Thong, S. Hydrogen and Methane Production from Starch Processing Wastewater by Thermophilic Two-stage Anaerobic Digestion. Energy Procedia 2015, 79, 827-832. [CrossRef]

27. Xie, L.; Dong, N.; Wang, L.; Zhou, Q. Thermophilic hydrogen production from starch wastewater using two-phase sequencing batch fermentation coupled with UASB methanogenic effluent recycling. Int. J. Hydrogen Energy 2014, 39, 20942-20949. [CrossRef]

28. Luo, W.; Zhao, Z.; Pan, H.; Zhao, L.; Xu, C.; Yu, X. Feasibility of butanol production from wheat starch wastewater by Clostridium acetobutylicum. Energy 2018, 154, 240-248. [CrossRef]

29. Ouephanit, C.; Virunanon, C.; Burapatana, V.; Chulalaksananukul, W. Butanol and ethanol production from tapioca starch wastewater by Clostridium spp. Water Sci. Technol. 2011, 64, 1774-1780. [CrossRef]

30. Tosungnoen, S.; Chookietwattana, K.; Dararat, S. Lactic Acid Production from Repeated-Batch and Simultaneous Saccharification and Fermentation of Cassava Starch Wastewater by Amylolytic Lactobacillus Plantarum MSUL 702. APCBEE Procedia 2014, 8 , 204-209. [CrossRef]

31. Huang, L.; Jin, B.; Lant, P.; Zhou, J. Simultaneous saccharification and fermentation of potato starch wastewater to lactic acid by Rhizopus oryzae and Rhizopus arrhizus. Biochem. Eng. J. 2005, 23, 265-276. [CrossRef] 
32. Stenberg, K.; Galbe, M.; Zacchi, G. The influence of lactic acid formation on the simultaneous saccharification and fermentation of softwood to ethanol. Enzyme Microb. Technol. 2000, 26, 71-79. [CrossRef]

33. Huang, L.; Jin, B.; Lant, P.; Zhou, J. Biotechnological production of lactic acid integrated with potato wastewater treatment by Rhizopus arrhizus. J. Chem. Technol. Biotechnol. 2003, 78, 899-906. [CrossRef] 